http://dx.doi.org/10.15407/ukrbotj72.01.046

Yu.Ya. TYKHONENKO, V.P. HAYOVA

M.G. Kholodny Institute of Botany, National Academy of Sciences of Ukraine

mycol@botany.kiev.ua

\title{
NEW RECORDS OF MILESINA BLECHNI AND MILESINA KRIEGERIANA (PUCCINIALES) FROM THE UKRAINIAN CARPATHIANS
}

\begin{abstract}
Tykhonenko Yu.Ya., Hayova V.P. New records of Milesina blechni and Milesina kriegeriana (Pucciniales) from the Ukrainian Carpathians. - Ukr. Bot. J. - 2015. - 72(1): 46-49.

Two species of Milesina (Pucciniales) collected in Gorgany Nature Reserve (Nadvirna District, IvanoFrankivsk Region) in September 2014 are reported, M. blechni (Syd. et P. Syd.) Arthur ex Faull on Blechnum spicant (L.) Roth and M. kriegeriana (Magnus) Magnus on Dryopteris carthusiana (Vill.) H.P. Fuchs. These species have not been recorded in Ukraine for about a hundred years. Both rusts were found in very humid sites. Numerous observations of the same host plants under less humid conditions revealed no fungi. Descriptions, micrographs (SEM and LM) and distribution maps for the studied fungi are provided.
\end{abstract}

Key words: Pucciniastraceae, rust fungi, Dryopteris, Blechnum, morphology, distribution, Ukraine.

\section{Introduction}

During our mycological survey in Gorgany Nature Reserve (Nadvirna District, Ivano-Frankivsk Region) in September 2014, rust fungi parasitizing two species of ferns, Blechnum spicant (L.) Roth and Dryopteris carthusiana (Vill.) H.P. Fuchs, were observed and collected. Both specimens were examined in the laboratory and identified as species of Milesina Magnus (Pucciniastraceae). Rust fungi of this genus have not been noted in Ukraine for nearly hundred years. Moreover, they found to be rarely recorded in most European countries. They are therefore reported here as interesting rare finds.

\section{Matherials and methods}

Specimens collected in the field were labelled and dried for further treatment. Urediniospores mounted in water or lactic acid were investigated by light microscopy. Photomicrographs were taken under Primo Star microscope, Canon A300 digital camera and AxioVision 4.7 software, used as well for measurements of microstructures. For scanning electron microscopy, samples were covered with an ultrathin coating of gold by ion beam sputtering unit JFC-1100. Images were obtained by scanning electron microscope JEOL JSM-6060 LA.

Analysis of general distribution is based on the data from published sources (Majewski, 1977; Poelt, Zwetko, 1997; Tănase, Negrean, 2007; etc.) and databases available through the Internet, including GBIF Portal (http://data.gbif.org), USDA Fungal Database (Farr, Rossman, 2014), The Fungal Records Database of Britain and Ireland (http://www.fieldmycology.net/frdbi/ frdbi.asp), etc.

(c) YU.YA. TYKHONENKO, V.P. HAYOVA, 2015
The specimens are deposited in the Mycological Herbarium of the M.G. Kholodny Institute of Botany, National Academy of Sciences of Ukraine $(K W)$.

\section{Results and discussion}

The synonymic names, description of uredinial stage, host plants and distribution data of the studied species are provided below. Original illustrations and distribution maps are followed by information on their morphology and ecology of these species.

Milesina blechni (Syd. et P. Syd.) Arthur ex Faull, Annls mycol. 8(5): 491. 1910. - Melampsorella blechni Syd. et P. Syd., Annls mycol. 1(6): 537. 1903. - Milesia blechni (Syd. et P. Syd.) Arthur ex Faull, Contrib. Arnold Arbor. 2: 37. 1932.

Uredinia hypophyllous, scattered or grouped on greenish-brown areas, pustular, $0.2-0.4 \mathrm{~mm}$ in diameter, yellowish, rupturing at a centrally placed stoma of the overlying epidermis (Fig. 1, $a$ ). Urediniospores colourless, obovoid to ellipsoid, $26-45 \times 15-23 \mu \mathrm{m}$, walls thin, $0.7-1.0 \mu \mathrm{m}$ thick, with scattered rather coarse echinulation (Fig. 1, $c, e$ ).

Distribution in Ukraine: On Blechnum spicant (L.) Roth: Ivano-Frankivsk Region, Kosiv, 48 $19^{\prime} \mathrm{N}, 25^{\circ} 5^{\prime}$ E, 06.1914 (Wróblewski, 1916); Ivano-Frankivsk Region, Verkhovyna, 48 9' N, 24 48’ E, 06.1914 (Wróblewski, 1916); Ivano-Frankivsk Region, Verkhovyna District, Pozhyzhevska, 48 ${ }^{\circ}$ 8 $^{\prime} \mathrm{N}, 2^{\circ}$ 31' E, 31.08.1911 (Wróblewski, 1922); Ivano-Frankivsk Region, Nadvirna District, Gorgany Nature Reserve, Chernyk parcel, south-west of Chernyk village, 18 quarter, forest of $\mathrm{Pi}$ cea abies (L.) H. Karst. and Abies alba Mill., along road at forest edge, $48^{\circ} 28^{\prime} \mathrm{N} 24^{\circ} 20^{\prime} \mathrm{E}, 10.09 .2014$, V.P. Hayova. 


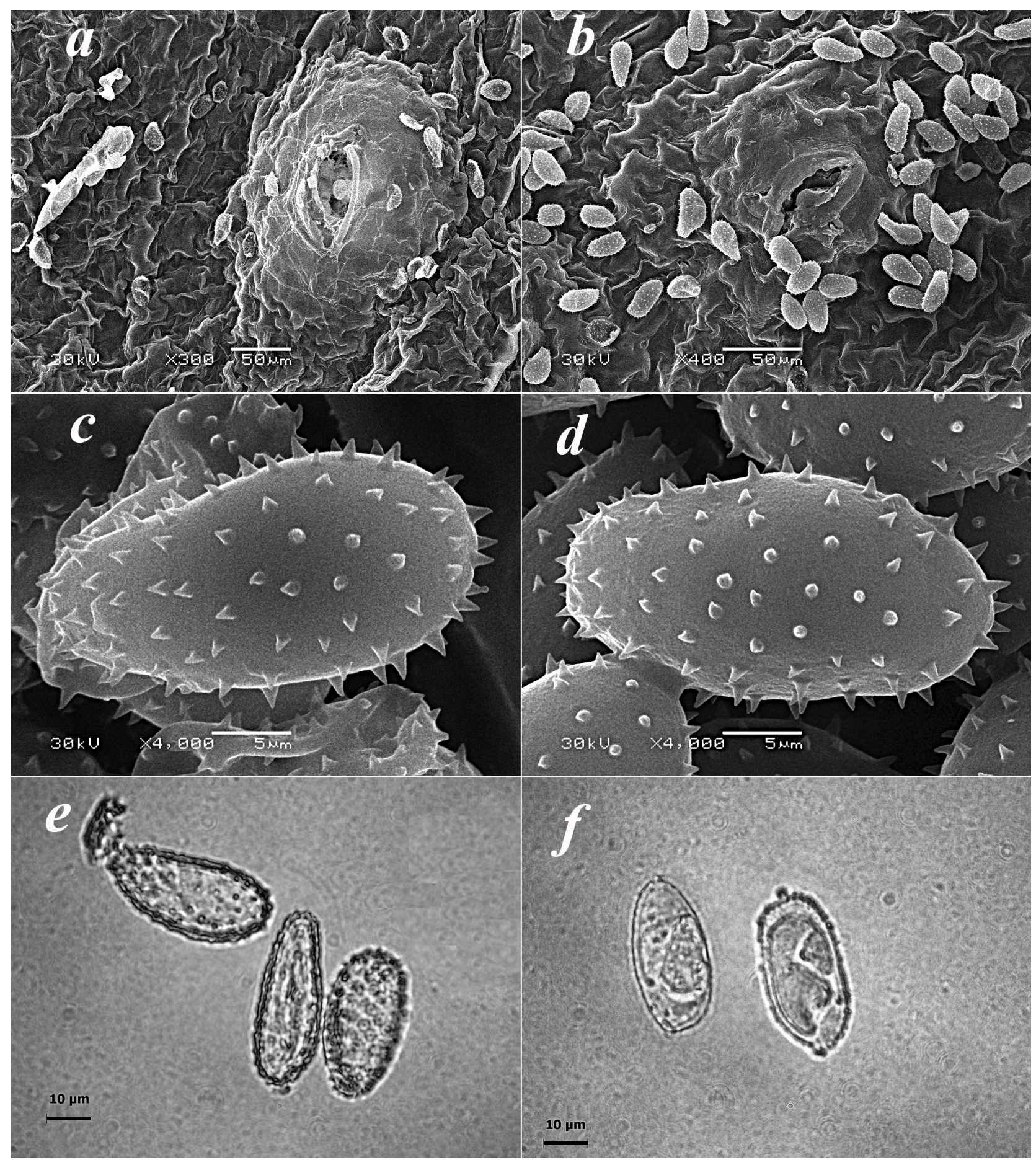

Fig 1. Milesina blechni on Blechnum spicant: $a$ - uredinium, $c, e$ - urediniospores; Milesina kriegeriana on Dryopteris carthusiana: $b$ - uredinium, $d, f$ - urediniospores $(a, b, c, d-\mathrm{SEM}, e, f-\mathrm{LM})$. Scale bars: $a, b-50 \mu \mathrm{m} ; c, d-5 \mu \mathrm{m} ; e, f-10 \mu \mathrm{m}$ 


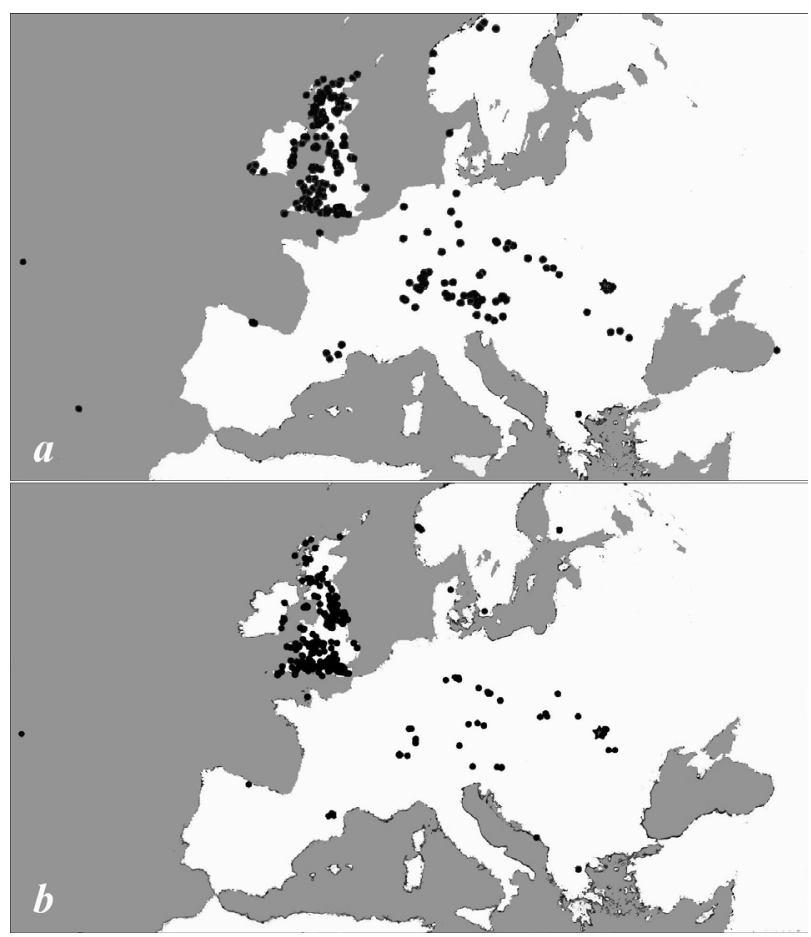

Fig. 2. Distribution maps for Milesina blechni (a) and Milesina kriegeriana $(b)$

General distribution: Austria, Belgium, Czech Republic, Denmark, France, Georgia, Germany, Greece, Ireland, Netherlands, Norway, Poland, Portugal, Romania, Spain, Sweden, Switzerland, Ukraine, United Kingdom (Fig. 2, $a$ ).

Milesina kriegeriana (Magnus) Magnus, Bull. Inst. Bot. Univ. Belgrade 27: 325. 1909. - Melampsorella kriegeriana Magnus, Bull. Inst. Bot. Univ. Belgrade 19: 581. 1901. - Milesia kriegeriana (Magnus) Arthur, Mycologia 7(4): 176. 1915.

Uredinia hypophyllous, scattered or grouped on greenish-brown areas, pustular, $0.1-0.3 \mathrm{~mm}$ in diameter, covered by brownish epidermis with centrally placed stomatic pore (Fig. 1, b). Urediniospores colourless, obovoid to ellipsoid, $23-48 \times 15-22 \mu$, walls thin, up to $1 \mu$ thick, clearly echinulate (Fig. $1, d, f$ ).

Distribution in Ukraine: On Dryopteris carthusiana (Vill.) H.P. Fuchs: Ivano-Frankivsk Region, Kolomyia District, Kniazhdvir, 48 33' N, 24 53' E, 09.1913 (Wróblewski, 1916); Ivano-Frankivsk Region, Nadvirna District, Gorgany Nature Reserve, Chernyk parcel, Novobudova, 36 quarter, forest of Picea abies (L.) H. Karst. and Abies alba Mill., forest edge, $48^{\circ} 24^{\prime}$ N 242' E, 09.09.2014, V.P. Hayova. On D. dilatata (Hoffm.) A. Gray: Ivano-Frankivsk Region, Kolomyia, $48^{\circ} 31^{\prime} \mathrm{N}, 25^{\circ} 2^{\prime} \mathrm{E}, 05.1914$ (Wróblewski, 1916); Iva-
no-Frankivsk Region, Kosiv District, Zawojely, $48^{\circ} 12^{\prime} \mathrm{N}$ $24^{\circ} 35^{\prime}$ E, A. Wróblewski. On D. filix-mas (L.) Schott: Ivano-Frankivsk Region, Kolomyia District, Kniazhdvir, 48 33' N, 24 53’ E, 09.1913 (Wróblewski, 1916); Ivano-Frankivsk Region, Kosiv District, Kosmach, $48^{\circ} 19^{\prime} \mathrm{N}, 24^{\circ} 48^{\prime} \mathrm{E}, 23.06 .1916$ (Wróblewski, 1922).

General distribution: Austria, Czech Republic, Denmark, Finland, France, Germany, Greece, Ireland, Montenegro, Norway, Poland, Portugal, Romania, Spain, Sweden, Switzerland, Ukraine, United Kingdom (Fig. 2, b).

Dryopteris filix-mas is also parasitized by $M$. carpatorum Hyl., Jørst. et Nannf., a species which is known to occur in Europe (former Czechoslovakia, Norway, Ukraine, UK) and Eastern Asia. Milesina carpatorum is distinguished from $M$. kriegeriana by its urediniospore size and surface ornamentation. The former species has much smaller urediniospores $(17-26 \times 12-16 \mu)$ as well as smaller and more dense echinulations scattered on their surface. In addition, M. carpatorum has not been reported on any other species of the genus Dryopteris Adans., except D. filix-mas.

Aecial stages of Milesina species, so far unrecorded in Ukraine, develop on Abies spp. The spermagonia and aecia display similar morphological features which are of little value in distinguishing Milesina species. Thus, in this genus uredinia and urediniospore size, spore surface ornamentation and identity of the uredinial host are determining for species delimitation.

Both M. blechni and M. kriegeriana are apparently European species; few reports of their occurrence outside Europe we regard as a result of long-distance dispersal or misidentification. Interestingly, the analysis of their distribution has shown that almost all known up to now records of these rusts are confined to mountainous or coastal regions. This is particularly well demonstrated within the relatively more explored areas with respect to rust fungi associated with ferns; for example, in the British Isles these species have been more rarely reported from inland localities.

The studied species are ecologically similar as they both show strong association with hygrophilous microhabitats, while their host plants frequently occur under less humid conditions. In this respect, a very relevant observation was made by N.W. Legon regarding one of the specimens of M. kriegeriana collected in South Somerset (United Kingdom): «Host plant common along the steep sided banks but the only ones with the rust were in a very damp micro-climate at the edges of a flooded culvert alongside the trackbed» (http://www.field- 
mycology.net/frdbi/frdbirecord.asp?pg=6). Similarly, M. Wilson and D.M. Henderson (1966) commented: «Uredospore production is most abundant on moribund leaves lying in damp conditions near the ground rather than on the functional leaves freely exposed in the air». Both our specimens were also collected in very humid sites on the montane forest fringes: M. kriegeriana - on the moist slope near springs, M. blechni - in a shallow ditch along the pathway. Our numerous observations of the same host plants and other fern species under less humid conditions revealed no fungi.

It can be suggested that M. blechni and M. kriegeriana occur in other localities in the Ukrainian Carpathians. The fact that up to now they have been extremely rarely reported from this region can be explained by a specific morphological trait of the Milesina and Uredinopsis species. In general appearance, the representatives of these two genera are fairly distinct from the common rust fungi. Unlike the majority of rusts, they have colourless (white in mass) urediniospores, whereas uredinia embedded in host tissue can be confused with the sporangia clustered into sori on fertile leaves of the host plant.

\section{Acknowledgements}

We are grateful to staff members of Gorgany Nature Reserve, particularly to M.B. Shpylchak, for their support during the field work.

\section{LITERATURE CITED}

Farr D.F., Rossman A.Y. Fungal Databases, Systematic Mycology and Microbiology Laboratory, ARS, USDA. http://nt.ars-grin.gov/fungaldatabases/ (23 December 2014).

Majewski T. Flora Polska. Grzyby (Mycota) 9: Basidiomycetes, Uredinales. I. - Warszawa-Kraków: PWN, 1977. - $396 \mathrm{~s}$.

Poelt J., Zwetko P. Die Rostpilze Österreichs. 2. revidierte und erweiterte Auflage des Catalogus Florae Austriae, III. Teil, Heft 1 Uredinales. - Wien: Österreichischen Akademie der Wissenschaften, 1997. - 365 S.

Tănase C., Negrean G. The genus Milesina Magnus (Fungi, Basidiomycota) in Romania // An. Stiint. Univ. Al. I. Cuza Iasi, Sect. II a. Biol. veget. - 2007. - 53. - P. 108-113.

Wilson M., Henderson D.M. British rust fungi. - London: Cambridge University Press, 1966. - 384 p.

Wróblewski A. Drugi przyczynek do znajomości grzybów Pokucia i Karpat Pokuckich // Sprawozdanie Komisji Fizjograficzney Polskiej Akademii Umiejętności. 1916. - 50. - S. 82-154.
Wróblewski A. Wykaz grzybów zebranych w latach 19131918 z Tatr, Pienin, Beskidów Wschodnich, Podkarpacia, Podola, Roztocza i innych miejscowości. I. Phycomycetes, Ustilaginaceae, Uredinales i Basidiomycetes // Sprawozdanie Komisji Fizjograficzney Polskiej Akademii Umiejętności. - 1922. - 55/56. - S. 1-50.

Recommended for publication by V.P. Heluta

Submitted 23.01.2015

Тихоненко Ю.Я., Гайова В.П. Нові знахідки Milesina blechni та Milesina kriegeriana (Pucciniales) з Українських Карпат. - Укр. ботан. журн., - 2015. - 72(1): 46-49.

Інститут ботаніки імені М.Г. Холодного НАН України, м. Київ

Повідомляється про знахідки на території природного заповідника «Горгани» (Івано-Франківська область, Надвірнянський район) двох видів роду Milesina Magnus, які не реєструвалися в Україні вже протягом майже ста років: Milesina blechni (Syd. et P. Syd.) Arthur ex Faull на Blechnum spicant (L.) Roth i Milesina kriegeriana (Magnus) Magnus на Dryopteris carthusiana (Vill.) H.P. Fuchs. Обидва види знайдені в дуже вологих місцезнаходженнях. Ураження живильних рослин цих видів у сухіших оселищах не спостерігалось. Робота ілюстрована шістьма мікрофотографіями виявлених іржастих грибів і картами їх поширення.

Клю и в в і слов в: Pucciniastraceae, іржасті гриби, Dryopteris, Blechnum, морфологія, поширення, Україна.

Тихоненко Ю.Я., Гаевая В.П. Новые находки Milesina blechni и Milesina kriegeriana (Pucciniales) из Украинских Карпат. - Укр. ботан. журн., - 2015. - 72(1): 46-49. Институт ботаники имени Н.Г. Холодного НАН Украины, г. Киев

Сообщается о находках на территории природного заповедника «Горганы» (Ивано-Франковская область, Надворнянский район) двух видов рода Milesina Magnus, которые не регистрировались в Украине уже на протяжении почти столетия: Milesina blechni (Syd. et P. Syd.) Arthur ex Faull на Blechnum spicant (L.) Roth и Milesina kriegeriana (Magnus) Magnus на Dryopteris carthusiana (Vill.) H.P. Fuchs. Оба вида собраны в очень влажных местонахождениях. Развитие ржавчины на питающих растениях этих видов в более сухих биотопах не наблюдалось. Работа иллюстрирована шестью микрофотографиями обнаруженных ржавчинников и картами их распространения.

Ключев в е слов а: Pucciniastraceae, ржавчинные грибы, Dryopteris, Blechnum, морфология, распространение, Украина. 

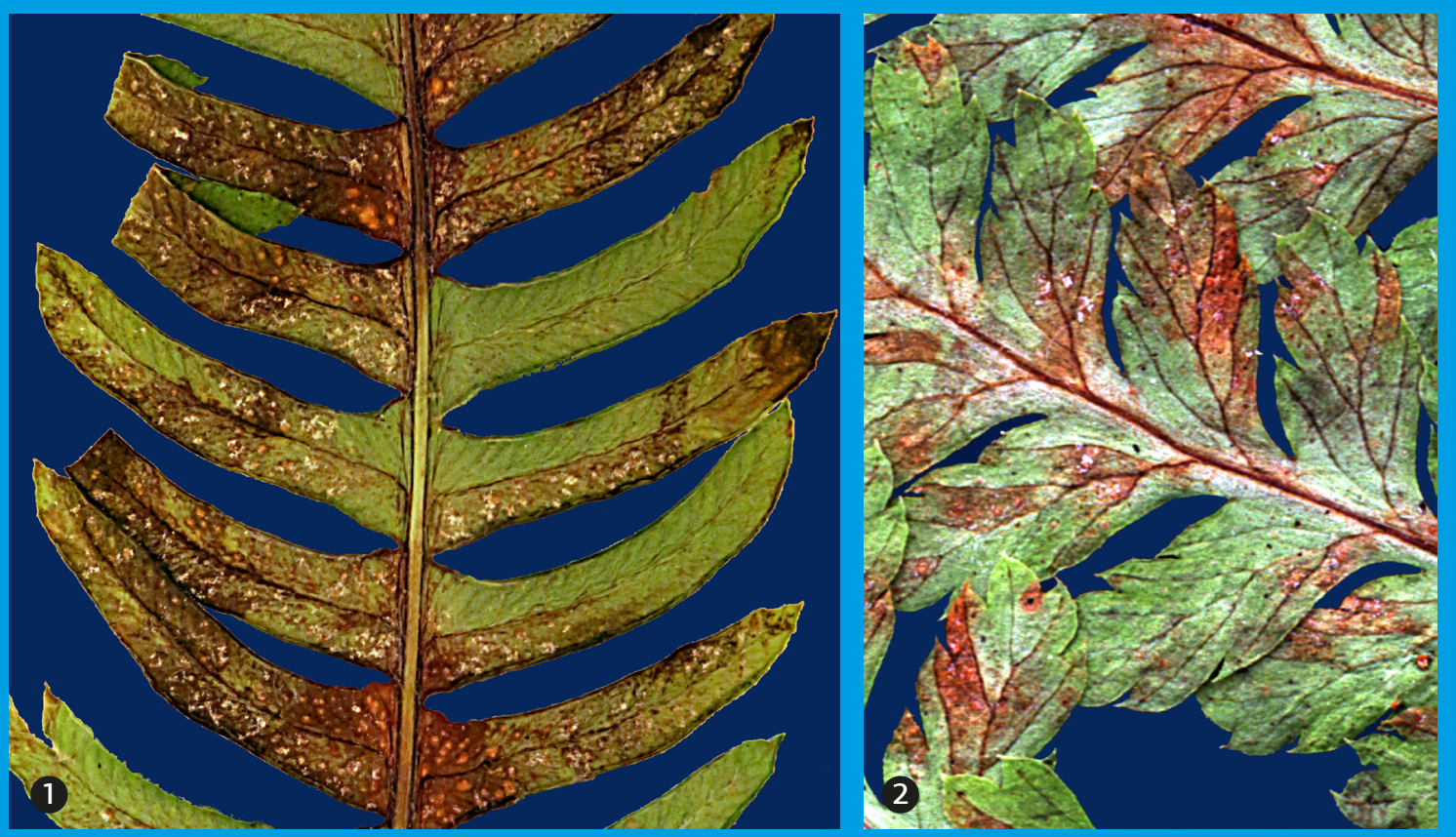

Uredinia of Milesina blechni on Blechnum spicant (1) and M. kriegeriana on Dryopteris carthusiana (2). Photos: V.P. Hayova, Yu.Ya. Tykhonenko (see pp. 46-49)

Урединії Milesina blechni на Blechnum spicant (1) і M. kriegeriana на Dryopteris carthusiana (2). Фото: В.П. Гайова, Ю.я. Тихоненко (див. сс. 46-49) 